\title{
Optimization of Osmotic Dehydration of Autumn Olive Berries Using Response Surface Methodology
}

\author{
Mohamed Ghellam ${ }^{1, *(D)}$, Oscar Zannou ${ }^{1}$ (D) Hojjat Pashazadeh ${ }^{1}\left(\mathbb{D}\right.$, Charis M. Galanakis $^{2,3,4}$ (D), $^{-}$ \\ Turki M. S. Aldawoud ${ }^{2}$, Salam A. Ibrahim ${ }^{5}$ iD and Ilkay Koca $^{1}$ \\ 1 Food Engineering Department, Faculty of Engineering, Ondokuz Mayis University, Samsun 55000, Turkey; \\ zannouoscar@gmail.com (O.Z.); hojjat_pashazadeh@yahoo.com (H.P.); itosun@omu.edu.tr (I.K.) \\ 2 Research \& Innovation Department, Galanakis Laboratories, 73100 Chania, Greece; \\ cgalanakis@chemlab.gr (C.M.G.); tdawoud@ksu.edu.sa (T.M.S.A.) \\ 3 Food Waste Recovery Group, ISEKI Food Association, 1190 Vienna, Austria \\ 4 Department of Botany \& Microbiology, College of Science, King Saud University, Riyadh 11451, Saudi Arabia \\ 5 Food and Nutritional Sciences Program, North Carolina A\&T State University, Greensboro, NC 27411, USA; \\ ibrah001@ncat.edu \\ * Correspondence: 16210571@stu.omu.edu.tr
}

Citation: Ghellam, M.; Zannou, O.; Pashazadeh, H.; Galanakis, C.M.; Aldawoud, T.M.S.; Ibrahim, S.A.; Koca, I. Optimization of Osmotic Dehydration of Autumn Olive Berries Using Response Surface Methodology. Foods 2021, 10, 1075. https:// doi.org/10.3390/foods10051075

Academic Editor: Conrad O. Perera

Received: 4 March 2021

Accepted: 22 March 2021

Published: 13 May 2021

Publisher's Note: MDPI stays neutral with regard to jurisdictional claims in published maps and institutional affiliations.

Copyright: (c) 2021 by the authors. Licensee MDPI, Basel, Switzerland. This article is an open access article distributed under the terms and conditions of the Creative Commons Attribution (CC BY) license (https:/ / creativecommons.org/licenses/by/ $4.0 /)$.

\begin{abstract}
Autumn olive fruits are a rich source of nutrients and functional compounds, making them functional foods against many diseases and cancers. To increase the consumption, its processing, and its transformation into new products would help spread them to the consumer's table. In this study, after giving an overview of the physicochemical characteristics and the antioxidant activity, the objective was to optimize the osmotic dehydration (OD) of the berries. Response surface methodology was used to investigate the effect of dehydration factors: syrup concentration (30-70\%), temperature $\left(20-70{ }^{\circ} \mathrm{C}\right)$, and fruit-to-syrup ratio $(1: 10-2: 10)$ on the water loss $(\mathrm{WL})$, sugar gain (SG), weight reduction $(\mathrm{WR})$, density $(\rho)$, water activity $\left(\mathrm{a}_{\mathrm{w}}\right)$, and total color change $(\Delta \mathrm{E})$ of fruits after $10 \mathrm{~h}$ of OD. Results obtained by employing Box-Behnken design (three variables, three levels), and significant terms of regression equations indicated that the syrup concentration and temperature variation are the most affecting factors on the previously mentioned independent variables (WL SG, WR, $\rho, a_{w}$, and $\Delta \mathrm{E}$ ). Fruits to syrup ratio appeared to have a significant effect only on WL. Under the optimum conditions found $\left(70 \%, 70{ }^{\circ} \mathrm{C}, 1.8: 10\right)$, the predicted values were $59.21 \% .19 .21 \%, 32.34 \%, 1.22 \mathrm{~g} / \mathrm{cm}^{3}$, 0.850 , and 3.65 for $\mathrm{WL}, \mathrm{SG}, \mathrm{WR}, \rho, \mathrm{a}_{\mathrm{w}}$, and $\Delta \mathrm{E}$, respectively.
\end{abstract}

Keywords: autumn olive; osmotic dehydration; optimization; response surface methodology

\section{Introduction}

The role of food bioactives in protecting consumers' health has been upgraded in the era of the COVID-19 pandemic [1,2]. Food bioactives are mainly found in fruits and vegetables [3]. For instance, autumn olive fruit (Elaeagnus umbellata) is a delicious reddish berry from the Elaeagnaceae family that comprises a good source of various nutrients and antioxidant compounds. These berries can contain more than 15 times more lycopene than tomatoes. Therefore, autumn olive berries can play a useful role in protecting consumers' health and reducing the risk of contracting many diseases [4,5]. These miraculous berries show great industrial potentials since they can be used and processed in food industries [6] and in pharmaceutical and cosmetic industries.

Autumn olive fruits are perishable within only a few days due to the high water content and high fragility of the fruit skin. Thus, these berries are vulnerable and need more attention during the harvest and postharvest processing. In order to increase their shelf life and decrease their vulnerability, these fruits can be subjected to many transformation or treatment techniques. Since water is the dominant component in fruits and vegetables, it plays a critical role in influencing foodstuffs' quality and stability due to the possible series 
of physicochemical and biological changes. Drying is one of the essential preservation techniques used to increase storage stability and reduce the packaging and transport costs, making commodities affordable in their off-seasons. This technique has been widely used for centuries $[7,8]$.

Osmotic dehydration (OD) can be used as a pre-treatment for a large number of foodstuffs (fruits, vegetables, meat, seafood, etc.) before performing the primary preservation process. It consists of reducing the initial water content [9]. Generally, the osmotic process appears to be a vital technique since it can preserve and improve the nutritional, organoleptic, and overall functional properties of osmosed products $[10,11]$. Osmotic treatment is a desirable process because of its effectiveness in preventing and minimizing discoloration and the loss of flavor, attributed to slight thermal damage (low temperatures) and delayed enzymatic browning reactions $[12,13]$. Furthermore, OD is, among drying technologies, described as a tool that requires less energy consumption and operational costs [8,9].

OD is generally defined as the partial removal of water from cellular materials by immersion in a hypertonic solution. The driving force applied by osmotic pressure triggers a mass transfer between the two media: a diffusion of water from the tissues into the osmotic solution, and, simultaneously, a counter-diffusion of solute from the solution into the cellular tissues. The diffusion takes place throughout the semi-permeable cell membrane. Therefore, OD is not only a water removal treatment but also a significant solute incorporation into food. Nonetheless, OD's application leads to a weight reduction of the osmotically treated product $[9,13]$.

Various products can be made through OD processes, including mainly candied and dried fruits and vegetables. These foods can be consumed directly or added as ingredients in many traditional and novel food products and preparations, including ice cream, bread, and cakes. OD can be followed by complementary treatment to continue the preservation process, such as drying (air/vacuum/freezing), freezing, canning, etc. Furthermore, this pre-treatment process has been recently combined with numerous techniques such as vacuum, centrifugal force, and high-intensity ultrasound. The applications of these treatments have greatly improved the mass transfer (solid gain and water loss) and the subsequent drying properties (rate and time), and hence, the final product quality [14-16].

Fruits and vegetables can be osmosed whole, in pieces, or in different sizes and shapes. Many osmotic media are applied as concentrated solutions (e.g., sucrose, sugar, corn syrup, salt). Several process parameters have been found to be critical for the mass transfer, such as the osmotic solution concentration, treatment temperature, solute properties, sample to solution ratio, agitation, time, pressure (vacuum, high pressure), and food characteristics (e.g., shape, size, structure, tissue compactness) [17].

At the start of this work, the physicochemical properties and antioxidant activity of autumn berries were determined to give a general overview of this nutrient-rich source and its potential activity. To the best of the authors' knowledge, no research has been published on the OD of autumn berries. It is believed that the dried autumn berries would find a large market and receive a similar appeal from consumers like other dried berries (blueberry, blackberry, and cranberries), grapes, and other fruits. Therefore, this study aimed to investigate the dehydration of autumn olive berries by OD as a function of syrup concentration, osmotic temperature, and sample to solution ratio. For this purpose, the response surface methodology was used to determine the optimum conditions for OD.

\section{Materials and Methods}

\subsection{Material and Chemical}

Autumn olive fruits were harvested from the Department of Horticulture's trial garden, Ondokuz Mayis University, Samsun, Turkey. Fruits were sorted, and the fruits with similar maturity (ripe red fruits) and shape were kept. Fruits were put into in refrigerator bags (ca. $300 \mathrm{~g}$ ) and immediately frozen at $-20^{\circ} \mathrm{C}$.

2,4,6-Tris(2-pyridyl)-1,3,5-triazine (TPTZ), 2,2-Diphenyl-1-Picrylhydrazyl (DPPH), 6hydroxy 2,5,7,8-tetramethylchroman-2-carboxylic acid (Trolox), 2,6-dichlorophenolindoph- 
enol, hydrochloric acid $(\mathrm{HCl}, 37 \%)$, methanol $(99.8 \%)$, acetone, oxalic acid, sodium nitrite, sodium hydroxide $(\mathrm{NaOH})$, and (-)-epicatechin $(\mathrm{Ep})$ were purchased from Sigma-Aldrich (St. Louis, MO, USA). Gallic acid (GA) and sodium carbonate from Riedel-de Haen (Seelze, Germany). Potassium chloride, sodium acetate, glacial acetic acid, and ascorbic acid (AA) from CARLO ERBA (Rodano, Italy). Aluminum chloride, Folin-Ciocalteau, iron chloride (Merck). Hexane (TEKKIM), BHT (butylated hydroxytoluene) (SAFC). Analytical balance (Radwag, AS 220/C/2, Radom, Poland), precision balance (Radwag, PS 3500.R1, Poland), hotplate stirrer (M TOPS, Multi-position), drying oven (NÜVE, FN 500P, Ankara, Turkey), shaking water bath (Model ST 30, NÜVE, Ankara, Turkey).

\subsection{Physico-Chemical Analyses}

The frozen fruits were sorted again from the damaged or crushed fruits, homogenized, and left to thaw at room temperature for the various analyses and the osmotic treatment. Afterward, the fruits were gently blotted with paper to remove the superficial humidity before being transferred.

pH was measured using a pH-meter (Model Starter 3100, OHAUS, Parsippany, NJ, USA). Titratable acidity (TA) was assessed and expressed as a malic acid concentration (\%) [18]. Length and width were measured by a digital caliper (TRESNA, Series: EC16, China). Lycopene and vitamin $C$ were determined according to Fish, Perkins-Veazie, and Collins [19]. The amount of total phenolic compounds (TPC) was measured spectrophotometrically at $760 \mathrm{~nm}$ according to the Folin-Ciocalteu method [20]. Total anthocyanin content was determined by the $\mathrm{pH}$ differential method [21]. Flavonoid content was determined using a spectrophotometric method based on the aluminum complex formation [22] The free radical scavenging capacity was assessed by using Diphenyl-1-Picrylhydrazyl (DPPH) as a free radical [22]. The reducing capacity of berry extracts was measured according to the method of Benzie and Strain [23]. Minor modifications were performed for many analyses. Calibration curves were used to calculate concentrations; curves prepared by the corresponding standards (Trolox, GA, AA, Ep) showed high values of determination coefficient $\left(R^{2}>0.990\right)$. The previously mentioned analysis was performed for fresh berries with many replications.

For both the fresh and osmosed fruits, water activity $\left(\mathrm{a}_{\mathrm{W}}\right)$ was determined using a calibrated water activity meter at $25 \pm 0.1^{\circ} \mathrm{C}$ (Aqualab, 4TE, WA, USA). The bulk density ( $\rho$ ) was measured according to Yang and Atallah [24]. Soluble solids contents (SSC) were analyzed by an Abbe refractometer (Model DTM-1, Atago, Tokyo, Japan). The fruits' color was measured using a digital colorimeter (Model CR-400, Minolta-Konica Sensing Inc., Osaka, Japan). The CIE L*a*b* scale was used, and the total color change $(\Delta \mathrm{E})$ of the treated samples was calculated as with Equation (1):

$$
\Delta \mathrm{E}=\sqrt{\left(l-l_{0}\right)^{2}+\left(a-a_{0}\right)^{2}+\left(b-b_{0}\right)^{2}}
$$

where $l_{0}, a_{0}, b_{0}$, and $l, a, b$, are the color parameters of fresh and treated fruits, respectively.

To determine moisture content, a homogenized quantity of the samples (ca. $5 \mathrm{~g}$ ) was taken and dried at $70{ }^{\circ} \mathrm{C}$ till at a constant weight. Moisture content $(\mathrm{M} \%)$ was calculated as follows:

$$
\mathrm{M}(\%)=\frac{\mathrm{W}_{\mathrm{i}}-\mathrm{W}_{\mathrm{f}}}{\mathrm{W}_{\mathrm{i}}} \times 100
$$

where $W_{i}$ and $W_{f}$ are the initial and final weights of the samples, respectively.

\subsection{Water Loss, Solute Gain, and Weight Reduction}

After the osmotic process, the mass transport of the fruits in sucrose solutions was expressed as water loss (WL), sugar gain (SG), and weight reduction (WR), and was determined according to the previous method [25]. The water loss was defined as the net loss of water from the autumn olive fruits (Equation (3)), the sugar gain as the net gain in 
total solids based on the initial mass (Equation (4)), and the weight reduction as the net mass reduction of the fruits based on the initial mass (Equation (5)).

$$
\begin{gathered}
W L=\frac{W_{i} X_{i}-W_{f} X_{f}}{W_{i}} \times 100 \\
S G=\frac{W_{f}\left(1-X_{f}\right)-W_{i}\left(1-X_{i}\right)}{W_{i}} \times 100 \\
W R=\frac{W_{i}-W_{f}}{W_{i}} \times 100
\end{gathered}
$$

where WL is the water loss (g water/g initial mass of autumn fruits)\%, SG is the sugar gain (g sugar/g initial mass of autumn fruits)\%, WR is the mass reduction $(\mathrm{g} / \mathrm{g}$ of the initial mass of autumn fruits)\%, $\mathrm{W}_{\mathrm{i}}$ is the initial mass of the autumn fruits $(\mathrm{g}), \mathrm{W}_{\mathrm{f}}$ is the mass of the autumn fruits after OD or at a specific time $(g), X_{i}$ is the water content as a fraction of the initial mass of the autumn fruits, and $X_{f}$ is the water content as a fraction of the mass of the fruits after OD.

\subsection{Osmotic Dehydration (OD)}

Osmotic solutions (syrups) at different concentrations $(30-70 \%, w / w)$ were prepared with distilled water and commercial sugar purchased from the local market. The concentration of the solutions was controlled continuously by the Abbe refractometer before each use. The solutions were poured in $500 \mathrm{~mL}$ beakers placed on hot plates, and the temperatures $\left(20-70{ }^{\circ} \mathrm{C}\right)$ were continuously controlled by a digital thermometer before and after adding the berries. The berries were added at different weight ratios to $400 \mathrm{~g}$ of solution (1:10-2:10). The beakers were tightly closed during the process to avoid water evaporation. The experimental time was fixed at $10 \mathrm{~h}$ for all experiments. Due to the low density of the fruits that floated on the surface and depending on the solution with the highest density (solution concentration), the agitation speed was fixed at $250 \mathrm{rpm}$ for all runs. At the end of the process, the fruits were gently taken from the osmotic solutions and rinsed with distilled water (ca. $20 \mathrm{~s}$ ). They were immediately blotted with paper to remove the excess surface water $(2-3 \mathrm{~min})$.

\subsection{Scanning Electron Microscope (SEM)}

Microstructures of the fresh and dried autumn olive berries were obtained by using SEM (JEOL JSM-7001F). A small specimen was cut from the samples and attached onto a stainless stub with double-sided sticky tape and sputtered immediately with a gold/palladium target (60/40) of approximately $10 \mathrm{~nm}$ using a sputter coater functioning with an argon and plasma current for $2 \mathrm{~min}$. The images were observed at an acceleration voltage of $10 \mathrm{kV}$.

\subsection{Experimental Design and Statistical Analysis}

Response surface methodology (RSM) is an empirical statistical modeling technique employed for multiple regression analyses using quantitative data obtained from adequately designed experiments to simultaneously solve multivariate equations [26]. RSM was used to estimate the main effects of process variables on the water loss (WL), solid gain $(\mathrm{SG})$, weight reduction $(\mathrm{WR})$, water activity $\left(\mathrm{a}_{\mathrm{w}}\right)$, density $(\rho)$, and color $(\Delta \mathrm{E})$ of the autumn berries. A Box-Behnken design was used for designing the experimental data. The independent variables were solution concentration $\left(X_{1}\right)$, temperature $\left(X_{2}\right)$, and fruit-to-solution ratio $\left(\mathrm{X}_{3}\right)$. Using statistical software (Design-Expert 10, Minneapolis, MN, USA), the design generated 17 runs, including 5 center points. The following second-order polynomial equation was used to fit the experimental data:

$$
Y_{i}=\beta_{0}+\beta_{0} X_{1}+\beta_{2} X_{2}+\beta_{3} X_{3}+\beta_{12} X_{1} X_{2}+\beta_{13} X_{1} X_{3}+\beta_{23} X_{2} X_{3}+\beta_{11} X_{1}^{2}+\beta_{22} X_{2}^{2}+\beta_{33} X_{3}^{2}
$$


where $Y_{i}$ is the response (WL, SG, WR, $\mathrm{a}_{\mathrm{w}}, \rho$ or $\left.\Delta \mathrm{E}\right), \beta_{n}$ is the constant regression coefficients, the variables $\mathrm{X}_{1}, \mathrm{X}_{2}$, and $\mathrm{X}_{3}$ are the solution concentration $(\% w / w)$, temperature $\left({ }^{\circ} \mathrm{C}\right)$, and fruit-to-solution ratio, respectively.

The statistical software Design-Expert 10 (Stat-Ease, Minneapolis, MN, USA) was used for statistical analysis, the generation of models, and the determination of optimum conditions and contours. Data were analyzed for the fitting of each model of the dependent variables (WL, SG, $W R, a_{w}, \rho$, or $\Delta E$ ) by multiple linear regression. The significance of the model $(p<0.05)$ was evaluated by analysis of variance (ANOVA) for each response. The adequacy of the models was checked in terms of a coefficient of determination $\left(R^{2}\right)$, adjusted coefficient of determination (Adj. $R^{2}$ ), prediction error sum of squares (PRESS), and a lack-of-fit value. The optimum conditions were calculated according to the desirability function by maximizing WL, SG, WR, and $\rho$, minimizing $\mathrm{a}_{\mathrm{W}}$, and $\Delta \mathrm{E}$, and keeping in range the independent variables. The non-significant factors were stepwise removed from the polynomial model.

\section{Results and Discussion}

\subsection{Physico-Chemical Characteristic and Antioxidant Activity of Autumn Berries}

In this work, the fresh, ripe berries of the autumn olive were analyzed to assess this fruit's chemical and physical properties. This evaluation allows for a better understanding of the general properties of the fruit before any treatment and transformation (i.e., osmotic treatment). The results obtained from the autumn berries are presented in Table 1.

Table 1. Physicochemical properties and antioxidant activity of autumn olive berries (in the present study and from the literature).

\begin{tabular}{|c|c|c|c|}
\hline \multicolumn{2}{|c|}{ Fruit Properties (Present Studies) Mean \pm S. D } & \multirow{2}{*}{$\begin{array}{c}\text { Fruits Properties (Previous Studies) } \\
\text { NF }\end{array}$} & \multirow{2}{*}{$\frac{\text { Reference }}{-}$} \\
\hline Color parameters: $\mathrm{L}^{*}$ & $31.53 \pm 1.20^{\mathrm{a}}$ & & \\
\hline$a^{*}$ & $6.10 \pm 1.23^{\mathrm{a}}$ & NF & - \\
\hline$b^{*}$ & $4.43 \pm 0.44^{\mathrm{a}}$ & NF & - \\
\hline \multirow{2}{*}{ Number of fruits/Weight (50 g of berries) } & \multirow[b]{2}{*}{$259 \pm 6^{b}$} & $17.54-18.40 \mathrm{~g} / 100$ berries & [6] \\
\hline & & $16.41-22.80 \mathrm{~g} / 100$ berries & {$[27]$} \\
\hline \multirow{2}{*}{ Length mm } & \multirow{2}{*}{$6.19 \pm 0.64^{c}$} & $6.99 \pm 0.13 \mathrm{~mm}$ & [28] \\
\hline & & $7.1-8.7 \mathrm{~mm}$ & {$[27]$} \\
\hline \multirow{2}{*}{ Width mm } & \multirow{2}{*}{$6.40 \pm 0.72^{c}$} & $3.78-4.28 \mathrm{~mm}$ & [6] \\
\hline & & $4.8-6.7 \mathrm{~mm}$ & [27] \\
\hline Density $(\rho) \mathrm{g} / \mathrm{cm}^{3}$ & $1.038 \pm 0.010^{\mathrm{d}}$ & NF & - \\
\hline Water activity $\left(\mathrm{a}_{\mathrm{w}}\right)$ & $0.955 \pm 0.007^{\mathrm{d}}$ & NF & - \\
\hline \multirow{2}{*}{ Moisture content (M.C\%. FW) } & \multirow{2}{*}{$77.24 \pm 0.41^{\mathrm{e}}$} & $78.49-81.71 \%$ & [5] \\
\hline & & $71.4 \pm 1.8 \%$ & {$[6]$} \\
\hline \multirow{3}{*}{ Soluble solids content (SSC: ${ }^{\circ}$ Brix) } & \multirow{3}{*}{$14.80 \pm 0.27^{\mathrm{f}}$} & $12.3-15.4$ & [29] \\
\hline & & $9.03-11.76$ & [6] \\
\hline & & $11-17$ & {$[30]$} \\
\hline \multirow{3}{*}{$\mathrm{pH}$} & \multirow{3}{*}{$3.07 \pm 0.03^{f}$} & $3.1-4.0$ & [29] \\
\hline & & $3.30-3.90$ & [6] \\
\hline & & $4.5 \pm 0.1$ & {$[5]$} \\
\hline \multirow{5}{*}{ Titratable acidity T.A\% (malic Acid\%) } & \multirow{5}{*}{$1.20 \pm 0.05^{g}$} & 0.79-1.29 (TA\%) FW & [31] \\
\hline & & 2.02-6.88 (Malic. A) mg/100 g FW & [31] \\
\hline & & $26.59 \pm 1.63 \mathrm{mg} / \mathrm{g}$ FW (total acids) & [28] \\
\hline & & $2.20-2.94 \% \mathrm{FW}$ & [6] \\
\hline & & $3.1 \pm 0.1 \% \mathrm{FW}$ & [5] \\
\hline \multirow{4}{*}{ Lycopene mg/100 g FW } & \multirow{4}{*}{$20.47 \pm 3.18^{g}$} & $33.6-55.3 \mathrm{mg} / 100 \mathrm{~g} \mathrm{FW}$ & [29] \\
\hline & & $19.9 \pm 3.2$ (T. Carotenoids) mg/g DW & {$[5]$} \\
\hline & & 30.58 to $46.23 \mathrm{mg} / 100 \mathrm{~g}$ FW & [31] \\
\hline & & $30-50 \mathrm{mg} / 100 \mathrm{~g}$ FW & [30] \\
\hline
\end{tabular}


Table 1. Cont.

\begin{tabular}{|c|c|c|c|}
\hline \multicolumn{2}{|c|}{ Fruit Properties (Present Studies) Mean \pm S. D } & \multirow{2}{*}{$\begin{array}{c}\text { Fruits Properties (Previous Studies) } \\
7.65-10.10 \mathrm{mg} / 100 \mathrm{~g} \mathrm{FW} \\
27.8 \pm 1.8 \mathrm{mg} / 100 \mathrm{~g} \mathrm{FW} \\
13.8-16.9 \mathrm{mg} / 100 \mathrm{~g} \mathrm{FW}\end{array}$} & \multirow{2}{*}{$\begin{array}{c}\text { Reference } \\
{[6]} \\
{[5]} \\
{[27]}\end{array}$} \\
\hline Vitamin C. mg A.A Eq/100 g & $7.17 \pm 2.27 \mathrm{~g}$ & & \\
\hline Total phenols. mg G.A. Eq/100 g FW & $287 \pm 40^{g}$ & $\begin{array}{c}\text { 1399-1833 mg/kg FW } \\
5.56 \text { mg/g DW } \\
\text { 168.9-258.1 mg G.A. Eq/100 g FW } \\
23.3 \pm 2.0 \text { mg/g DW } \\
\text { 16.3-20.0 mg G.A. Eq/g FW } \\
\text { 1700 mg Chlorogenic. A. Eq/kg FW } \\
\text { 190-275 mg GA Eq/100 g FW }\end{array}$ & $\begin{array}{l}{[29]} \\
{[32]} \\
{[19]} \\
{[5]} \\
{[33]} \\
{[30]} \\
{[34]}\end{array}$ \\
\hline Flavonoids mg-(-) Ep. Eq/100 g FW & $25.26 \pm 3.78^{g}$ & $\begin{array}{c}3.6 \pm 0.1 \mathrm{mg} / \mathrm{g} \mathrm{DW} \\
1.5-3.8 \mathrm{mg} \text { quercetin. Eq/g FW }\end{array}$ & $\begin{array}{c}{[5]} \\
{[33]}\end{array}$ \\
\hline DPPH. mMol Trolox. Eq/100 g FW & $494 \pm 48^{g}$ & $\begin{aligned} \mathrm{IC}_{50}=0.13 \pm 0.01 \mathrm{mmol} \text { of Trolox.Eq} / \mathrm{g} \mathrm{DW} \\
\text { IC50 }=2.42-5.37 \mathrm{mg} \text { of FW } \\
\text { IC50 }=45.40-49.00 \mu \mathrm{g} / \mathrm{mL}\end{aligned}$ & $\begin{array}{l}{[32]} \\
{[35]} \\
{[33]}\end{array}$ \\
\hline FRAP. mMol. Trolox. Eq/100 g FW & $718 \pm 43^{g}$ & NF & - \\
\hline Total anthocyanins. mg cyanidin. Eq/100 g FW & ND & ND & [32] \\
\hline
\end{tabular}

(-): No reference was found, Eq: Equivalent. NF: Not found in the literature. ND: Not detected. FW: Fresh weight. DW: Dry weight. Superscripts a, b, c, d, e, f, and g are the number of replications $15,6,20,3,8,5$, and 4, respectively.

The color of the berries was a mixture of brightness $\left(\mathrm{L}^{*}=31.53\right)$, redness $\left(\mathrm{a}^{*}=6.10\right)$, and yellowness $\left(\mathrm{b}^{*}=4.43\right)$. The water activity $\left(\mathrm{a}_{\mathrm{w}}\right)$ and density $(\rho)$ were determined as 0.955 and $1.04 \mathrm{~g} / \mathrm{cm}^{3}$, respectively. The color, density, and water activity of autumn olive berries have not been determined in the literature so far. However, the rest of the expected results are following the previous studies carried out for several ecotypes and genotypes of autumn berries (Table 1). For instance, pH, T.A (Malic acid\%), SSC, M.C, length, and width were $3.07,1.20 \%, 14.8 \%, 77.24 \%, 6.19 \mathrm{~mm}$, and $6.40 \mathrm{~mm}$, respectively.

Likewise, many nutrients and compounds exhibited similar contents to those of the literature. In $100 \mathrm{~g}$ of fresh fruits, lycopene, vitamin C (ascorbic acid), TPC, and flavonoids were $20.47 \mathrm{mg}$, $7.17 \mathrm{mg}$ (AA Eq), $287 \mathrm{mg}$ (GA Eq), and $25.26 \mathrm{mg}$ (Ep. Eq), respectively. Total anthocyanins were not detected either in the current study or in the study carried out by Spínola, Pinto, Llorent-Martínez, and Castilho [32]. It was reported that the phenolic compound contents were similar to those of strawberries and blueberries [34]. Additionally, regarding fruit flavor, astringency has been attributed to the high content of total phenolic compounds [30]. Flavonols appear to be the most abundant compounds, making up $79 \%$ of the autumn berries' phenolic compositions [32]. Lycopene is typically used as a natural pigment [36], while phenolic compounds can be used as bioactive ingredients in foods and cosmetics [37].

According to previous studies (Table 1) and due to the high content of phenolic compounds, carotenoids (lycopene), and vitamin C, the calculation of DPPH revealed interesting values. This confirmed the existence of increased antioxidant activity and the ability to scavenge free radicals. In the present study, DPPH and FRAP, representing the ability to quench and reduce free radicals, were spectrophotometrically measured. They revealed a high antioxidant potential, where DPPH and FRAP gave 494 and $718 \mathrm{mMol}$ Trolox Eq in $100 \mathrm{~g}$ of fresh weight, respectively.

Due to the contained phytonutrient and functional compounds, autumn berries are widely believed to decrease the occurrence of many ailments (e.g., myocardial infection) and cancer types (e.g., prostate) [5,27]. The extracts of these berries have proved their inhibitory activity against the transcription factors associated with carcinogenesis, as well as against the proliferation of cancer cells [31]. Besides the antioxidant and cancer inhibitory activities, previous studies have shown that autumn olive berries can exhibit action against diabetes (T2DM) and obesity [32].

In addition to phytonutrients, the existence of oil, various sugars, and minerals make these fruits a real source of nutrients [5,27]. With respect to flavor and taste, organoleptic 
evaluation of the berries showed interesting acceptability [6]. As such, the possession of such nutritional value and such functional power would induce the consumption and use of these berries, thereby producing novel products and supplement formulations.

\subsection{Optimization Process}

\subsubsection{Analysis of the Model}

In order to study the effect of OD factors (syrup concentration $X_{1}$, temperature $X_{2}$, and fruit-to-syrup ratio $X_{3}$ ) and to optimize the dehydration process, the experiment was performed using RSM of Box-Behnken design. The experimental data of different responses (SG, WR, WL, $\rho, \mathrm{a}_{\mathrm{W}}$, and $\Delta \mathrm{E}$ ), together with experimental points (17 runs), were presented in Table 2. The responses for different combinations showed a wide variation for all mass transfer dependent variables (SG, WR, $\mathrm{WL}, \rho$, and $\mathrm{a}_{\mathrm{W}}$ ) and color change $(\Delta \mathrm{E})$. The range values of 1.32-27.02, 12.76-43.62, 14.24-58.48, 1.06-1.23, 0.838-0.973, and 3.10-6.65 were obtained for SG, $\mathrm{WR}, \mathrm{WL}, \rho, \mathrm{a}_{\mathrm{W}}$, and $\Delta \mathrm{E}$, respectively. The highest $\mathrm{WR}, \mathrm{WL}$, and $\rho$ were obtained in run $7\left(70 \%\right.$ Brix, $70{ }^{\circ} \mathrm{C}$ and 1.5:10 ratio), while the highest SG was identified at run $15\left(70 \%\right.$ Brix, $45^{\circ} \mathrm{C}$ and 2:10 ratio), the highest $\mathrm{a}_{\mathrm{w}}$ at run $8\left(30 \%\right.$ Brix, $20^{\circ} \mathrm{C}$ and $\left.1.5: 10\right)$, and the highest $\Delta \mathrm{E}$ at run $13\left(50 \%\right.$ Brix, $20^{\circ} \mathrm{C}$ and $1: 10$ ratio). The lowest values of WR, $\mathrm{WL}$, and $\rho$ were detected at run $8\left(30 \%\right.$ Brix, $20^{\circ} \mathrm{C}$ and $1.5: 10$ ratio), while the lowest $S G$, $\mathrm{a}_{\mathrm{w}}$, and $\Delta \mathrm{E}$ were obtained at run $16\left(30 \%\right.$ Brix, $45^{\circ} \mathrm{C}$ and $1: 10$ ratio), run $7\left(70 \%\right.$ Brix, $70{ }^{\circ} \mathrm{C}$ and 1.5:10 ratio), and run $10\left(70 \%\right.$ Brix, $45^{\circ} \mathrm{C}$ and 1:10 ratio), respectively. These findings showed that high $X_{1}$ and $X_{2}\left(70 \%\right.$ Brix and $\left.\geq 45^{\circ} \mathrm{C}\right)$ had an essential effect on increasing the mass transfer between the fruit and dehydration medium.

Table 2. Uncoded Box-Behnken design independent variables and experimental data of observed responses.

\begin{tabular}{cccccccccc}
\hline \multirow{2}{*}{ Run } & \multicolumn{7}{c}{ Factors } & \multicolumn{7}{c}{ Responses } \\
\cline { 2 - 10 } & $\mathbf{X}_{\mathbf{1}}$ & $\mathbf{X}_{\mathbf{2}}$ & $\mathbf{X}_{\mathbf{3}}$ & $\begin{array}{c}\mathbf{S G} \\
\mathbf{\%}\end{array}$ & $\begin{array}{c}\mathbf{W R} \\
\mathbf{\%}\end{array}$ & $\begin{array}{c}\mathbf{W L} \\
\mathbf{\%}\end{array}$ & $\begin{array}{c}\mathbf{\rho} \\
\mathbf{g} / \mathbf{c m}^{\mathbf{3}}\end{array}$ & $\mathbf{a}_{\mathbf{w}}$ & $\mathbf{\Delta E}$ \\
\hline 1 & 50 & 45 & $1.5: 10$ & 5.79 & 25.11 & 30.91 & 1.10 & 0.951 & 3.95 \\
2 & 70 & 20 & $1.5: 10$ & 3.67 & 15.83 & 19.50 & 1.11 & 0.967 & 5.14 \\
3 & 50 & 45 & $1.5: 10$ & 5.52 & 23.79 & 29.32 & 1.10 & 0.957 & 3.75 \\
4 & 30 & 45 & $2: 10$ & 2.04 & 19.02 & 21.06 & 1.09 & 0.967 & 3.76 \\
5 & 50 & 45 & $1.5: 10$ & 6.60 & 24.12 & 30.72 & 1.11 & 0.955 & 3.75 \\
6 & 50 & 45 & $1.5: 10$ & 12.93 & 21.43 & 34.36 & 1.13 & 0.937 & 4.67 \\
7 & 70 & 70 & $1.5: 10$ & 14.85 & 43.62 & 58.48 & 1.23 & 0.838 & 3.13 \\
8 & 30 & 20 & $1.5: 10$ & 1.48 & 12.76 & 14.24 & 1.06 & 0.973 & 6.14 \\
9 & 50 & 20 & $2: 10$ & 4.75 & 16.66 & 21.41 & 1.09 & 0.962 & 6.38 \\
10 & 70 & 45 & $1: 10$ & 9.33 & 26.76 & 36.08 & 1.11 & 0.936 & 3.10 \\
11 & 30 & 70 & 1.5 .10 & 5.15 & 23.70 & 28.85 & 1.11 & 0.958 & 3.23 \\
12 & 50 & 70 & $2: 10$ & 14.58 & 27.60 & 42.18 & 1.21 & 0.918 & 4.18 \\
13 & 50 & 20 & 1.10 & 4.44 & 16.54 & 20.98 & 1.10 & 0.961 & 6.65 \\
14 & 50 & 45 & $1.5: 10$ & 11.61 & 22.71 & 34.32 & 1.12 & 0.941 & 3.80 \\
15 & 70 & 45 & $2: 10$ & 27.02 & 19.74 & 46.77 & 1.19 & 0.875 & 4.24 \\
16 & 30 & 45 & $1: 10$ & 1.32 & 18.38 & 19.70 & 1.07 & 0.971 & 4.00 \\
17 & 50 & 70 & $1: 10$ & 18.30 & 17.59 & 35.89 & 1.19 & 0.914 & 5.44 \\
\hline
\end{tabular}

$\mathrm{X}_{1:}$ Syrup concentration $(\%), \mathrm{X}_{2}$ : Temperature $\left({ }^{\circ} \mathrm{C}\right), \mathrm{X}_{3}$ : Fruit-to-syrup ratio (1:10-2:10). Responses are the mean of three replications.

Multiple linear regression analysis techniques analyzed second-order quadratic polynomial models for predicting the different responses. Stepwise regression was applied to identify only the significant terms and to remove the non-significant ones $(p<0.05)$ (Table 3), leading to the reduced equations. The adequacy and the fitness of the models were tested by ANOVA, together with regression coefficients and the corresponding determination coefficient $\left(R^{2}\right)$, Adj- $R^{2}$, and the lack-of-fit tests (Table 3). Response surface plots were generated for all significant responses as a function of two independent variables. The regression equations that describe the effects of the process variables in terms of uncoded 
factors on the various responses as a function of syrup concentration $\left(X_{1}\right)$, temperature $\left(X_{2}\right)$, and fruit-to-solution ratio $\left(X_{3}\right)$ were given as follows:

$$
\begin{gathered}
\mathrm{SG}=8.79+5.61 \mathrm{X}_{1}+4.82 \mathrm{X}_{2} \\
\mathrm{WR}=22.08+4.01 \mathrm{X}_{1}+6.34 \mathrm{X}_{2} \\
\mathrm{WL}=30.87+9.62 \mathrm{X}_{1}+11.16 \mathrm{X}_{2}+2.34 \mathrm{X}_{3}+6.09 \mathrm{X}_{1} \mathrm{X}_{2} \\
\rho=1.11+0.037 \mathrm{X}_{1}+0.047 \mathrm{X}_{2}+0.024 \mathrm{X}_{2}^{2} \\
\mathrm{a}_{\mathrm{W}}=0.94-0.032 \mathrm{X}_{1}-0.029 \mathrm{X}_{2}-0.029 \mathrm{X}_{1} \mathrm{X}_{2} \\
\Delta \mathrm{E}=4.20-1.04 \mathrm{X}_{2}-0.70 \mathrm{X}_{1}^{2}+1.19 \mathrm{X}_{2}^{2}
\end{gathered}
$$

\subsubsection{Effects of Independent Variables on Mass Transfer Responses (WL, WR, and SG)}

The results of runs and ANOVA analyses were given in Tables 2 and 3, respectively. As can be seen from these tables, ANOVA analyses showed that $\mathrm{R}^{2}$ for WL was 0.9457, and the adjusted $R^{2}$ was 0.9277 . These coefficients were found to be higher than those of WR and SG, which were less than 0.6000. Moreover, the coefficient of variation $(\mathrm{CV} \%)$ was $9.84 \%, 21.67 \%$, and $55.66 \%$ for $\mathrm{WL}, \mathrm{WR}$, and SG, respectively. The lack of fit was not significant for WL $(p<0.2414)$ and SG $(p<0.2156)$. However, the lack of fit of WR was substantial $(p<0.0087)$. The models developed for WL, WR, and SG were significant. Thus, these models can be used to navigate the design space.

The linear terms of $X_{1}$ and $X_{2}$ of the WR and SG models were significant, while their quadratic and interaction terms had no significant effect $(p>0.05)$ on these responses. The linear terms $\mathrm{X}_{1}, \mathrm{X}_{2}$, and $\mathrm{X}_{3}$ had a considerable effect on WL $(p<0.0001)$. Additionally, only the interaction $X_{1 \times 2}$ had a significant impact on WL. The effects of independent variables on WL, SG, and WR were shown in 3D plots (Figure 1a-e). The response surface showed the variables $X_{1}$ and $X_{2}$ in $3 D$ plots as they highly influenced the responses SG and WR, while kept the variable $X_{3}$ at its central point (1.5:10) as it was indifferent. The increase of variables $X_{1}$ and $X_{2}$ increased SG and WR linearly during osmotic treatment. The highest WR was obtained with the combination of $70 \%$ Brix and $70{ }^{\circ} \mathrm{C}$. The highest for SG was identified with the combination of $70 \%$ Brix and $45^{\circ} \mathrm{C}$. For the response of SG, the variable $X_{1}$ was found to be more influential than the variable $X_{2}$ with $F$ values of 10.52 and 7.76. For WR, the $X_{2}$ variable was found to be more influential than the $X_{1}$ variable, with $F$ values of 14.04 and 5.62 , respectively.

The WL was influenced by all the independent variables investigated in this study. The increase of $X_{1}$ (F value 107.99) and $X_{2}$ (F value 80.32) was found to show a stronger increase in $\mathrm{WL}$, suggesting that they had the most significant effects on this response. These results were following fundamental osmotic treatment theories, where the pressure gradient and driving force for mass transfer are strongly linked to syrup concentration and temperature [38]. However, the increase in the fruit-to-syrup ratio has shown a slight increase in WL. It has been previously shown that the increase of the syrup concentration and temperature had a significant effect on the increase of effective diffusivity for both water and sucrose [38]. In general, the syrup concentration and temperature were reported to positively affect the WL and SG of the osmo-dehydrated fruits. Recently, the highest WL and SG in papaya cubes have been recorded at the highest concentration and temperature $\left(60 \% \mathrm{Bix}, 70^{\circ} \mathrm{C}\right)$, and vice versa, the lowest values at the lowest concentration and temperature $\left(30 \%\right.$ Brix, $\left.30^{\circ} \mathrm{C}\right)[39]$. 
Table 3. Analysis of variance (ANOVA) for variable responses, and the coefficient predicted by quadratic reduced models.

\begin{tabular}{|c|c|c|c|c|c|c|c|c|c|c|c|c|c|c|c|c|c|c|}
\hline & & SG & & & WR & & & WL & & & $\rho$ & & & $a_{w}$ & & & $\Delta \mathrm{E}$ & \\
\hline & CE & SS & $p$-Value & CE & SS & $p$-Value & CE & SS & $p$-Value & $\mathrm{CE}$ & SS & $p$-Value & CE & SS & $p$-Value & CE & SS & $p$-Value \\
\hline Model & 8.79 & 437.53 & 0.0029 & 22.08 & 450.15 & 0.0022 & 30.87 & 1928.89 & $<0.0001$ & 1.11 & 0.031 & $<0.0001$ & 0.94 & 0.018 & $<0.0001$ & 4.2 & 16.3 & $<0.0001$ \\
\hline$X_{1}$ & 5.61 & 251.79 & 0.0059 & 4.01 & 128.75 & 0.0326 & 9.62 & 740.62 & $<0.0001$ & 0.037 & 0.011 & 0.0004 & -0.032 & $7.95 \times 10^{-3}$ & $<0.0001$ & - & - & - \\
\hline$X_{2}$ & 4.82 & 185.74 & 0.0146 & 6.34 & 321.4 & 0.0022 & 11.16 & 995.81 & $<0.0001$ & 0.047 & 0.018 & $<0.0001$ & -0.029 & $6.91 \times 10^{-3}$ & - & 1.04 & 8.66 & 0.0002 \\
\hline$X_{3}$ & - & - & - & - & - & - & 2.34 & 43.98 & 0.0496 & - & - & - & - & - & - & - & - & - \\
\hline $\mathrm{X}_{1} \mathrm{X}_{2}$ & & & & & & & 6.09 & 148.48 & 0.0017 & - & & & & $3.31 \times 10^{-3}$ & 0.0001 & - & - & - \\
\hline$x_{1} x_{3}$ & - & - & - & - & - & - & - & - & - & - & - & - & - & - & - & - & - & - \\
\hline$x_{2} x_{3}$ & - & - & - & - & - & - & - & - & - & - & - & - & - & - & - & - & - & - \\
\hline $\mathrm{X}_{1}^{2}$ & - & - & - & - & - & - & - & - & - & - & - & - & - & - & - & -0.7 & 2.08 & 0.0236 \\
\hline$x_{3}^{2}$ & - & - & - & - & - & - & - & - & - & - & - & - & - & - & - & - & - & - \\
\hline Residual & & 335.04 & & & 335.04 & & & 110.65 & & & $6.49 \times 10^{-3}$ & & & $3.08 \times 10^{-3}$ & & & 4.11 & \\
\hline $\begin{array}{c}\text { Lack of } \\
\text { Fit }\end{array}$ & & 285.91 & 0.2156 & & 312.54 & 0.0087 & & 89.68 & 0.2414 & & $5.98 \times 10^{-3}$ & 0.3775 & & $2.78 \times 10^{-3}$ & 0.0933 & & 3.49 & 0.1928 \\
\hline Total & & 772.57 & & & 770.66 & & & 2039.54 & & & 0.038 & & & 0.021 & & & 20.41 & \\
\hline$R^{2}$ & & 0.5663 & & & 0.5841 & & & 0.9457 & & & 0.8281 & & & 0.855 & & & 0.7988 & \\
\hline Adj- $R^{2}$ & & 0.5044 & & & 0.5247 & & & 0.9277 & & & 0.7884 & & & 0.8216 & & & 0.7524 & \\
\hline Pred- $R^{2}$ & & 0.3178 & & & 0.2747 & & & 0.8621 & & & 0.6674 & & & 0.7374 & & & 0.637 & \\
\hline $\mathrm{CV} \%$ & & 55.66 & & & 21.67 & & & 9.84 & & & 1.99 & & & 1.64 & & & 12.69 & \\
\hline
\end{tabular}

The terms and model are significant at $p<0.05$, lack of fit is not significant at $p>0.05$. 


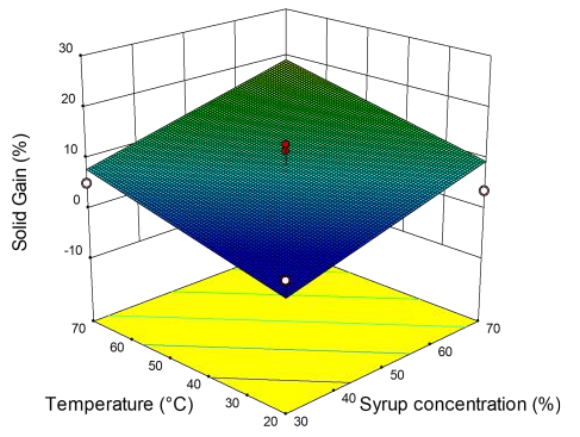

(a) 1.5:10 Fruit ratio

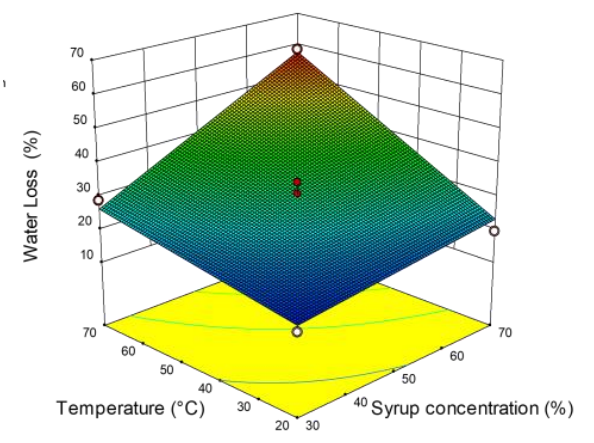

(c) $1.5: 10$ Fruit ratio

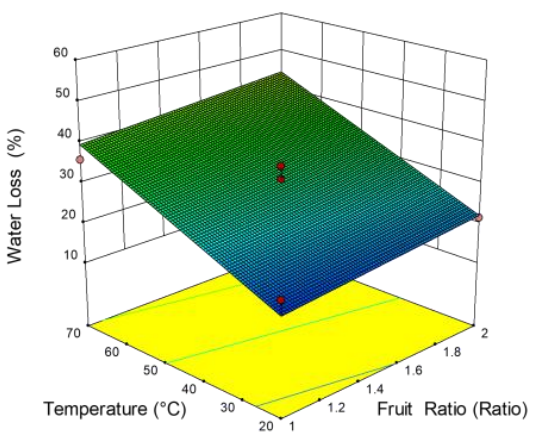

(e) $50 \%$ Syrup concentration

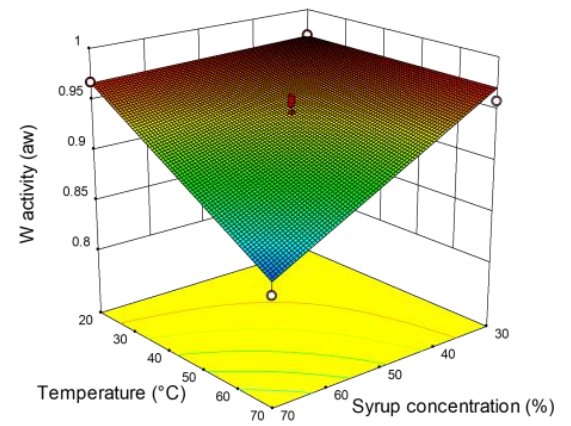

(g) 1.5:10 Fruit ratio

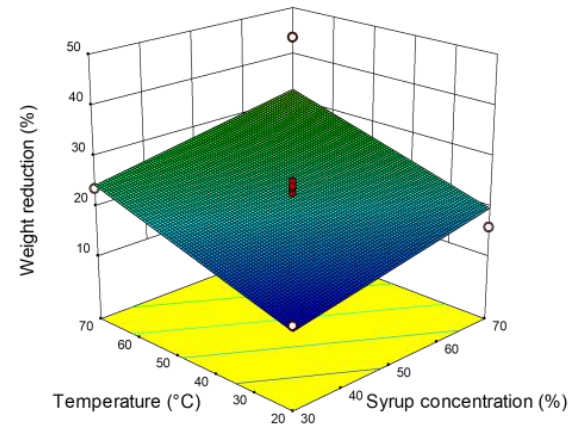

(b) 1.5:10 Fruit ratio

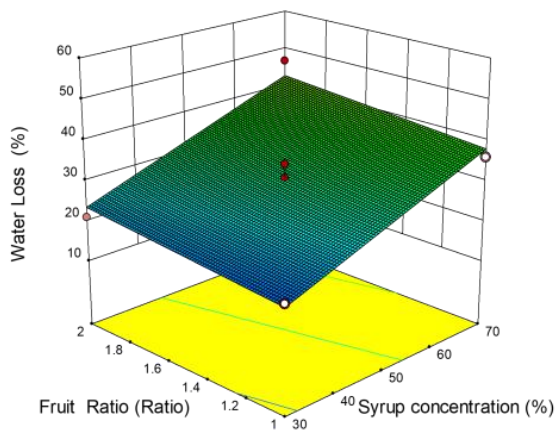

(d) $45{ }^{\circ} \mathrm{C}$ Temperature

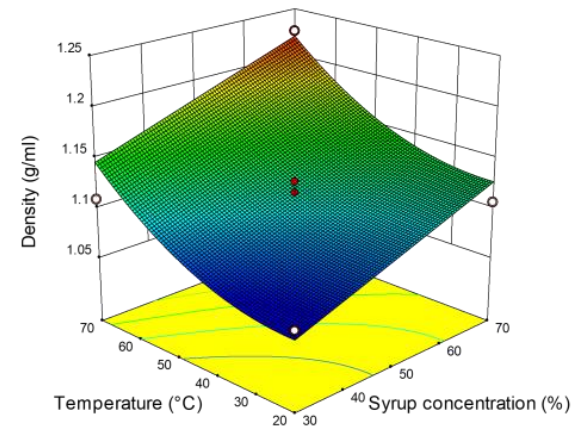

(f) 1.5:10 Fruit ratio

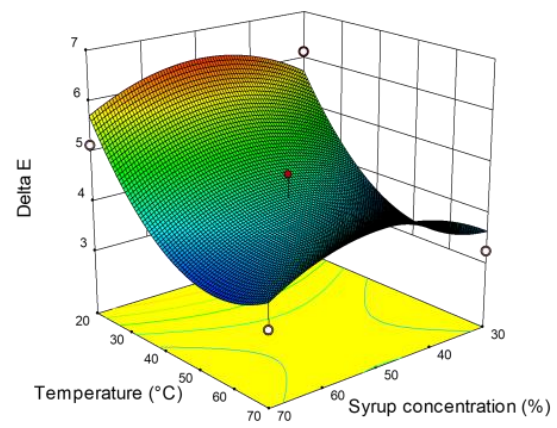

(h) 1.5:10 Fruit ratio

Figure 1. Response surface plots for different mass transfer parameters SG (a), WR (b), WL (c-e), $\rho(\mathbf{f}), \mathrm{a}_{\mathrm{w}}(\mathbf{g}), \Delta \mathrm{E}(\mathbf{h})$ during the osmotic dehydration of autumn olive berries. 
The mass transfer is influenced by many factors, including temperature, solute concentration and nature, food-to-solution ratio, and food characteristics. The purpose of drying defines the selection of parameters that lead to the desired results (e.g., fruit candying requires a high solid gain besides eliminating water) [9]. A gradual increase of solute concentration rises gradually up the gradient and the driving force between the fruit and the osmotic medium. Furthermore, the application of high temperature accelerates this process. The mass transfer is a temperature-dependent process since a higher temperature has been recognized to promote faster water transfer due to the possible swelling and plasticizing of cell membranes [40] and the decrease of viscosity of the osmotic medium [38]. It was pronounced to find WL percentage higher than SG and WR, since the rate of water removal is much higher than that of the solute penetration, which was favored by the molecular weight difference $[9,26]$. The increase of syrup-to-fruit ratio over $5: 1$ has been found to cause a higher rate of WL 9 and mass transfer in amla and apricot [26,41]. However, higher amounts of syrup means more costs for the drying process. Therefore, a lower syrup-to-fruit ratio (solution volume) with a high mass transfer rate is preferred.

\subsubsection{Effects of Independent Variables on Density}

The density variation might give a clear idea about the mass transfer process. As can be seen in the Table 3, $R^{2}$ was 0.8281 , and the adjusted $R^{2}$ was 0.7884 . The $R^{2}$ and adjusted $R^{2}$ generated for density were quite close, suggesting conformity between the experimental and predicted data. The coefficient of variation (CV\%) was 1.99, and the lack of fit was not significant $(0.0643)$. Thus, the model was adequate for predicting density and navigating the design space. The model showed that the linear terms of $X_{1}$ and $X_{2}$ had positive effects on density by inducing its increase. However, only the quadratic term of $\mathrm{X}_{2}$ had a significant impact on the density.

Response surface plots demonstrated the relationship between independent variables $\left(X_{1}\right.$ and $\left.X_{2}\right)$ and density (Figure $\left.1 \mathrm{f}\right)$. The increases in the two variables have individually increased the density value. The fresh fruits' (1.04) density rose by the osmosed fruits to reach its peak at 1.23. This increase could be attributed to the penetration of sugar (high density) and water removal. Furthermore, the elimination of entrapped gases due to process conditions and temperature contributed widely to increment the density of the treated berries.

Similarly, in previous studies, the increases in temperature and syrup concentration rose to a certain level of the bulk density of many fruits and vegetables. The osmotic pretreatment increased the strawberries' density from 1.08 to 1.29 [42]. The temperature and syrup concentration increased the sugar infusion and the release of air, which promoted water removal and lowered the osmotic medium's viscosity. Moreover, the modification of the tissue structure and the relaxation of the tissue could play a crucial role in increasing the bulk density [16]. Furthermore, a limited gas phase was retained, inducing volume loss and shrinkage $[43,44]$. The high bulk density can be desired as a response to the OD process depending on the final product's further uses.

\subsubsection{Effects of Independent Variables on $\Delta \mathrm{E}$}

The results of ANOVA of the effects of $X_{1}, X_{2}$, and $X_{3}$ were given in Table 3 . As can be seen, $R^{2}$ was 0.7988 , and adjusted $R^{2}$ was 0.7524 . The closeness of $R^{2}$ and adjusted $R^{2}$ indicated that there is excellent conformity between the experimental and predicted data of $\triangle \mathrm{E}$. CV was determined as $12.69 \%$, and the lack of fit was not significant (0.1928), implying that the model was adequate for predicting the color change and navigating the design space. For this model, only the linear term of $\mathrm{X}_{2}$ had significant effects on $\Delta \mathrm{E}$, where the decrease of $X_{2}$ increased the color change in autumn olive berries significantly. Meanwhile, both quadratic terms of $X_{1}$ and $X_{2}$ presented significant effects on the color change. $X_{2}$ was the most significant $\mathrm{F}$ value $18.78(p<0.001)$.

The sharp decrease in $\Delta \mathrm{E}$ started from $20^{\circ} \mathrm{C}$ and reached a valley between 50 and $60^{\circ} \mathrm{C}$ before a small increase from 60 to $70^{\circ} \mathrm{C}$ (Figure 1h). Although $\mathrm{X}_{1}$ was almost indifferent, 
at $50 \%$ concentration, the highest color change occurred. These results were in agreement with previous studies [45]. The color change can be explained by the enzymatic browning reactions that occurred at low temperatures. Additionally, the increase of temperature and syrup concentrations inactivates the oxidative enzymes progressively and increases the solid uptake, reducing oxygen availability $[46,47]$. Generally, the osmotic pre-treatments helped to reduce the effect of subsequent drying on color (less browning) to obtain food products (apples, grapes) with better characteristics.

\subsubsection{Effects of Independent Variables on Water Activity}

The results showing the effect of the independent variables on water activity $\left(a_{w}\right)$ were given in Table 2. For the model developed for water activity (Table 3), $R^{2}$ was found to be 0.8550 , adjusted $R^{2}$ was 0.8216 , and CV was $1.64 \%$. The lack of fit was not significant (0.0933), indicating that the model was adequate for predicting the water activity and navigating the design space. The linear terms of $X_{1}$ with an $F$ value of 33.55 and $X_{2}$ with a linear $F$ value of 29.16 were found to have significant effects on water activity. The interaction term $X_{1} X_{2}$ had a significant effect, while no quadratic terms showed significant water activity effects.

The increase of $X_{1}$ and $X_{2}$ was revealed to positively reduce the water activity (Figure $1 \mathrm{~g}$ ). The combined effects of these variables led to reducing water activity to 0.838 at higher values of $70 \%$ Brix and $70{ }^{\circ} \mathrm{C}$. This can be explained on the one hand by the water removal due to the osmosis phenomenon, or on the other hand, by the solute gain and the possible interactions of existing molecular water with solute molecules. It has been previously observed that high solute concentration (salt, sucrose) and temperature have reduced the water activity to less than 0.800 in potatoes. The solute gain is inevitable [48]. Likewise, long osmo-concentration time $(12 \mathrm{~h})$ significantly reduced the water activity in blueberries [16]. This supported our results since the experimental time was set to $10 \mathrm{~h}$ in this study.

\subsubsection{Multi-Response of Optimization}

In this study, the parameters investigated ranged from 30 to $70 \%$, from 20 to $70{ }^{\circ} \mathrm{C}$ and from 1:10 to 2:10 for syrup concentration $\left(\mathrm{X}_{1}\right)$, temperature $\left(\mathrm{X}_{2}\right)$, and fruit-to-syrup ratio $\left(X_{3}\right)$, respectively. The second-order polynomial models were used for each response to determine the specified optimum conditions to obtain the desired product. The desirability function was used to optimize the OD process. The criteria consisted of maximizing the water loss and bulk density and minimizing the water activity. Since the dehydrated product is targeted for confectionery, it should be kept for a long storage period by decreasing the water content and increasing the solute uptake. The optimum point was found to be at $70 \%, 70{ }^{\circ} \mathrm{C}$, and 1.8:10 for solution concentration, temperature, and fruit-to-solution ratio, respectively. Under these optimum conditions, the predicted values were $59.21 \% .19 .21 \%$, $32.34 \%, 1.22 \mathrm{~g} / \mathrm{cm}^{3}, 0.850$, and 3.65 for $\mathrm{WL}, \mathrm{SG}, \mathrm{WR}, \rho, \mathrm{a}_{\mathrm{W}}$, and $\Delta \mathrm{E}$, respectively.

\subsection{Effects of Drying on Microstructure}

The microstructural differences induced by the application of osmotic dehydration were shown by SEM images (Figure 2). The SEM analysis was undertaken on the fresh fruit and the fruit osmo-dehydrated at $70 \%, 70{ }^{\circ} \mathrm{C}$, and $1.8: 10$ for solution concentration, temperature, and fruit-to-solution ratio, respectively (optimum conditions). As can be seen, the microstructure of the fresh fruit is a massive amorphous structure with some alveoli-like zones on the surface (Figure 2a). After the osmotic dehydration process, the fruit's microstructure became smoother, with some cracks on the surface (Figure 2b). This observation denoted that the osmotic dehydration process affected the overall mass transport properties of the tissue. Moreover, the cells shrunk, and some of them collapsed after the water loss. Similar observations have been previously reported for many products $[26,49,50]$. 


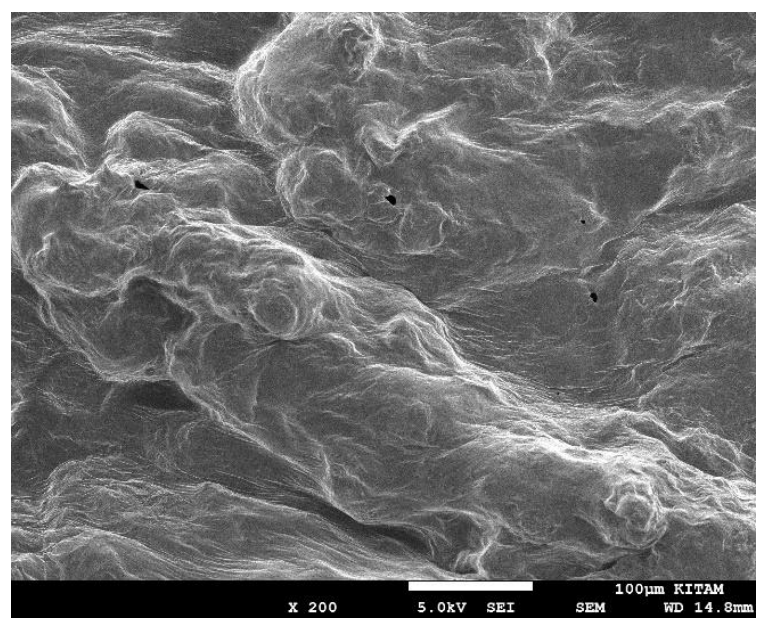

(a)

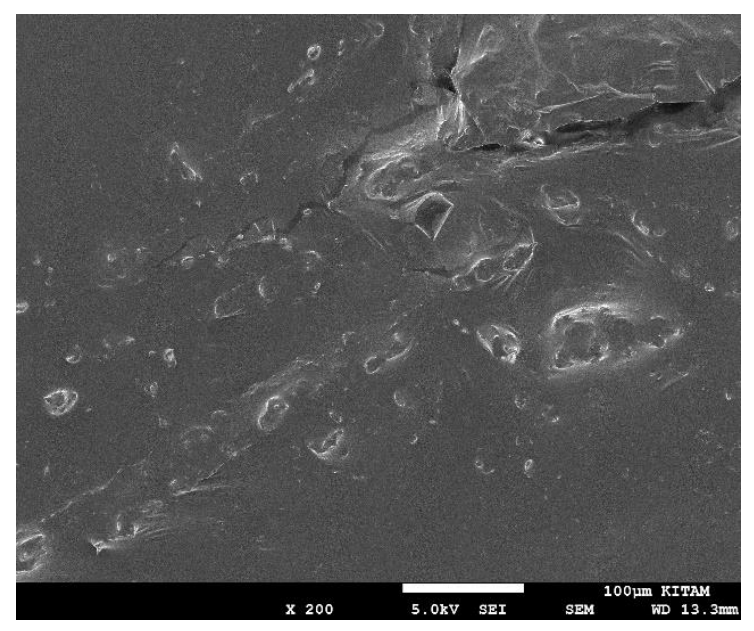

(b)

Figure 2. Microstructures of fresh (a) and osmo-dehydrated (b) autumn olive berries.

\section{Conclusions}

After determining the initial nutritional composition and antioxidant activity, autumn olive berries confirmed the importance of their consumption and its transformation into multiple products. The Box-Behnken plan was also used to study the effect of three independent variables (syrup concentration, temperature, and fruit-to-syrup ratio) on the different responses (WL SG, WR, $\rho, a_{w}$, and $\Delta E$ ) during the osmotic dehydration of these berries. In this research, the concentration and temperature of the syrup were the most effective factors in all responses. However, the fruit-to-syrup ratio factor was only significant on the WL of autumn berries after $10 \mathrm{~h}$ of treatment. The regression equations obtained can be used to predict the optimal conditions for the desired product. By applying the desirability function, maximizing the WL and $\rho$, and minimizing the $\mathrm{a}_{\mathrm{w}}$, the optimal point was $70 \%, 70{ }^{\circ} \mathrm{C}$, and 1.8:10 for syrup concentration, temperature, and fruit-to-syrup ratio, respectively. At this point, $\mathrm{WL}, \mathrm{SG}, \mathrm{WR}, \rho, \mathrm{a}_{\mathrm{W}}$, and $\Delta \mathrm{E}$ responses were $59.21 \%$, $19.21 \%, 32.34 \%, 1.22 \mathrm{~g} / \mathrm{cm}^{3}, 0.850$, and 3.65 , respectively. As a result, autumn berries' osmotic dehydration can be a good way to reduce the water content and a useful tool before conventional drying (air-drying, freeze-drying). This finding can be helpful for industrial applications. Despite the number of achieved responses, many analyses (texture, shrinkage) and sensorial investigation can be researched to target the final product with desired specifications.

Author Contributions: Conceptualization, M.G., O.Z., H.P. and I.K.; methodology, M.G., O.Z., H.P. and I.K.; validation, I.K., C.M.G., T.M.S.A. and S.A.I.; formal Analysis, M.G., O.Z. and H.P.; data curation, I.K., C.M.G., T.M.S.A. and S.A.I.; writing-original draft preparation, M.G. and O.Z.; writing-review and editing, C.M.G., T.M.S.A. and S.A.I.; supervision, I.K.; project administration, I.K., C.M.G. and S.A.I.; funding acquisition, S.A.I. All authors have read and agreed to the published version of the manuscript.

Funding: This research received no external funding.

Institutional Review Board Statement: Not applicable.

Informed Consent Statement: Not applicable.

Data Availability Statement: Data sharing not applicable. 
Acknowledgments: The participation of the authors Turki M. S. Aldawoud and Charis M. Galanakis in this work was supported by the Researchers Supporting Project number (RSP-2021/197) of King Saud University, Riyadh, Saudi Arabia. Authors (S.A.I.) would also like to acknowledge the support of the Agricultural Research Station at North Carolina Agricultural and Technical State University (Greensboro, NC 27411, USA). This research was funded, in part, by grants (project Number NC.X3375-21-170-1 and NC.X341-5-21-170-1) from the National Institute of Food and Agriculture (NIFA). Its contents are solely the responsibility of the authors and do not necessarily represent the official views of NIFA.

Conflicts of Interest: The authors have no conflict of interest to declare.

\section{References}

1. Galanakis, C.M. The Food Systems in the Era of the Coronavirus (COVID-19) Pandemic Crisis. Foods 2020, 9, 523. [CrossRef]

2. Galanakis, C.M.; Aldawoud, T.M.S.; Rizou, M.; Rowan, N.; Ibrahim, S. Food Ingredients and Active Compounds against the Coronavirus Disease (COVID-19) Pandemic: A Comprehensive Review. Foods 2020, 9, 1701. [CrossRef]

3. Galanakis, C.M. Separation of functional macromolecules and micromolecules: From ultrafiltration to the border of nanofiltration. Trends Food Sci. Technol. 2015, 42, 44-63. [CrossRef]

4. Galanakis, C.M. Phenols recovered from olive mill wastewater as additives in meat products. Trends Food Sci. Technol. 2018, 79, 98-105. [CrossRef]

5. Fordham, I.M.; Clevidence, B.A.; Wiley, E.R. Fruit of autumn olive: A rich source of lycopene. HortScience 2001, 36, 1136-1137. [CrossRef]

6. Khattak, K.F. Free radical scavenging activity, phytochemical composition and nutrient analysis of Elaeagnus umbellata berry. J. Med Plants Res. 2012, 6, 5196-5203. [CrossRef]

7. Hussain, I. Physiochemical and sensory Characteristics of Elaeagnus umbellata (Thunb) fruit from Rawalakot (Azad Kashmir) Pakistan. Afr. J. Food Sci. 2011, 2, 151-156.

8. Fernandes, F.A.N.; Rodrigues, S.; Gaspareto, O.C.P.; Oliveira, E.L. Optimization of osmotic dehydration of papaya followed by air-drying. Food Res. Int. 2006, 39, 492-498. [CrossRef]

9. Sagar, V.R. Recent advances in drying and dehydration of fruits and vegetables: A review. J. Food Sci. Technol. 2010, 47, 15-26. [CrossRef]

10. Rastogi, N.K.; Raghavarao, K.S.M.S.; Niranjan, K.; Knorr, D. Recent developments in osmotic dehydration: Methods to enhance mass transfer. Trends Food Sci. Technol. 2002, 13, 48-59. [CrossRef]

11. Galanakis, C.M. Emerging technologies for the production of nutraceuticals from agricultural by-products: A viewpoint of opportunities and challenges. Food Bioprod. Process. 2013, 91, 575-579. [CrossRef]

12. Galanakis, C.M. Functionality of Food Components and Emerging Technologies. Foods 2021, 10, 128. [CrossRef] [PubMed]

13. Lerici, C.R.; Pinnavaia, G.; Dalla, M.; Bartolucci, L. Osmotic dehydration of fruit: Influence of osmotic agents on drying behavior and product quality. J. Food Sci. 1985, 50, 1217-1219. [CrossRef]

14. Torreggiani, D. Osmotic dehydration in fruit and vegetable processing. Food Res. Int. 1993, 26, 59-68. [CrossRef]

15. Azuara, E.; Garciab, H.S.; Beristain, C.I. Effect of the centrifugal force on osmotic dehydration of potatoes and apples. Food Res. Int. 1996, 29, 195-199. [CrossRef]

16. Bozkir, H.; Rayman, A.; Serdar, E.; Metin, G.; Baysal, T. Ultrasonics-Sonochemistry Influence of ultrasound and osmotic dehydration pre-treatments on drying and quality properties of persimmon fruit. Ultrason. Sonochem. 2019, 54, 135-141. [CrossRef]

17. Stojanovic, J.; Silva, J.L. Influence of osmoconcentration, continuous high-frequency ultrasound and dehydration on properties and microstructure of rabbiteye blueberries. Dry. Technol. 2006, 24, 165-171. [CrossRef]

18. Cao, H.; Zhang, M.; Mujumdar, A.S.; Du, W.H.; Sun, J.C. Optimization of Osmotic Dehydration of Kiwifruit Optimization of Osmotic Dehydration of Kiwifruit. Dry. Technol. 2006, 24, 89-94. [CrossRef]

19. Sadler, G.D.; Murphy, P.A. pH and titratable acidity. In Food Analysis; Springer: Boston, MA, USA, $2010 ;$ pp. $219-238$.

20. Fish, W.W.; Perkins-veazie, P.; Collins, J.K. A Quantitative assay for lycopene that utilizes reduced volumes of organic solvents. J. Food Compos. Anal. 2002, 15, 309-317. [CrossRef]

21. Zannou, O.; Koca, I. Optimization and stabilization of the antioxidant properties from Alkanet (Alkanna tinctoria) with natural deep eutectic solvents. Arab. J. Chem. 2020, 13, 6437-6450. [CrossRef]

22. Zannou, O.; Koca, I.; Aldawoud, T.M.S.; Galanakis, C.M. Recovery and stabilization of anthocyanins and phenolic antioxidants of roselle (Hibiscus sabdariffa L.) with hydrophilic deep eutectic solvents. Molecules 2020, 25, 3715. [CrossRef] [PubMed]

23. Pękal, A.; Pyrzynska, K. Evaluation of Aluminium Complexation Reaction for Flavonoid Content Assay. Food Anal. Methods 2014, 7, 1776-1782. [CrossRef]

24. Benzie, I.F.F.; Strain, J.J. The ferric reducing ability of plasma (FRAP) as a measure of "antioxidant power": The FRAP assay. Anal. Biochem. 1996, 76, 70-76. [CrossRef]

25. Yang, C.S.T.; Atallah, W.A. Effect of four drying methods on the quality of intermediate moisture lowbush blueberries dehydration time determination. J. Food Sci. 1985, 50, 1233-1237. [CrossRef] 
26. Jain, S.K.; Verma, R.C.; Murdia, L.K.; Jain, H.K.; Sharma, G.P. Optimization of process parameters for osmotic dehydration of papaya cubes. J. Food Sci. Technol. 2011, 48, 211-217. [CrossRef] [PubMed]

27. Ahmad, S.D.; Sabir, S.M.; Zubair, M. Ecotypes diversity in autumn olive (Elaeagnus umbellata Thun): A single plant with multiple micronutrient genes. Chem. Ecol. 2006, 22, 509-521. [CrossRef]

28. Wu, M.C.; Hu, H.T.; Yang, L.; Yang, L. Proteomic Analysis of up-accumulated proteins associated with fruit quality during autumn olive (Elaeagnus umbellata) fruit ripening. J. Agric. Food Chem. 2011, 59, 577-583. [CrossRef]

29. Black, B.L.; Fordham, I.M.; Perkins-Veazie, P. Autumn berry (Elaeagnus umbellata): A potential cash crop. J. Am. Pomol. Soc. 2005, 59, 125-134.

30. Pei, R.; Yu, M.; Bruno, R.; Bolling, B.W. Phenolic and tocopherol content of autumn olive (Elaeagnus umbellate) berries. J. Funct. Foods 2015, 16, 305-314. [CrossRef]

31. Wang, S.Y.; Bowman, L.; Ding, M. Variations in free radical scavenging capacity and antiproliferative activity among different genotypes of autumn olive (Elaeagnus umbellata). Planta Med. 2007, 53, 468-477. [CrossRef]

32. Tiroutchelvame, D.; Sivakumar, V.; Maran, J.P. Mass transfer kinetics during osmotic dehydration of amla (Emblica officinalis L.) cubes in sugar solution. Chem. Ind. Chem. Eng. Q. 2015. [CrossRef]

33. Ishaq, S.; Rathore, H.A.; Sabir, S.M.; Maroof, M.S. Antioxidant properties of Elaeagnus umbellata berry solvent extracts against lipid peroxidation in mice brain and liver tissues. Food Sci. Biotechnol. 2015, 24, 673-679. [CrossRef]

34. Spínola, V.; Pinto, J.; Llorent-Martínez, E.J.; Castilho, P.C. Changes in the phenolic compositions of Elaeagnus umbellata and Sambucus lanceolata after in vitro gastrointestinal digestion and evaluation of their potential anti-diabetic properties. Food Res. Int. 2019, 122, 283-294. [CrossRef] [PubMed]

35. Wang, S.Y.; Fordham, I.M. Differences in chemical composition and antioxidant capacity among different genotypes of Autumn Olive (Elaeagnus umbellata Thunb.). Food Technol. Biotechnol. 2007, 45, 402-409.

36. Nagarajan, J.; Prasad, N.K.; Ramakrishnan, N.R.; Raghunandan, M.E.; Galanakis, C.M.; Wei, O.C. A facile water-induced complexation of lycopene and pectin from pink guava byproduct: Extraction, characterization and kinetic studies. Food Chem. 2019, 296, 47-55. [CrossRef]

37. Rahmanian, N.; Jafari, S.M.; Galanakis, C.M. Recovery and removal of phenolic compounds from olive mill wastewater. J. Am. Oil Chem. Soc. 2014, 91, 1-18. [CrossRef]

38. Mercali, G.D.; Marczak, L.D.F.; Tessaro, I.C.; Noreña, C.P.Z. Osmotic dehydration of bananas (Musa sapientum, shum.) in ternary aqueous solutions of sucrose and sodium chloride. J. Food Process Eng. 2012, 35, 149-165. [CrossRef]

39. Barragán-Iglesias, J.; Rodríguez-Ramírez, J.; Sablani, S.S.; Méndez-Lagunas, L.L. Texture analysis of dried papaya (Carica papaya L. cv. Maradol) pretreated with calcium and osmotic dehydration. Dry. Technol. 2019, 37, 906-919. [CrossRef]

40. Lazarides, H.N.; Katsanidis, E. Mass transfer kinetics during osmotic preconcentration aiming at minimal solid uptake. J. Food Eng. 1995, 25, 151-166. [CrossRef]

41. Khoyi, M.R.; Hesari, J. Osmotic dehydration kinetics of apricot using sucrose solution. J. Food Eng. 2007, 78, 1355-1360. [CrossRef]

42. Viberg, U.; Freuler, S.; Gekas, V.; Sjiiholm, I. Pre-treatment of strawberries effects and shrinkage. J. Food Eng. 1997, 35, 135-145. [CrossRef]

43. Mavroudis, N.E. Osmotic dehydration of apples. Shrinkage phenomena and the significance of initial structure on mass lkansfer rates. J. Food Eng. 1998, 38, 101-123. [CrossRef]

44. Mayor, L.; Moreira, R.; Sereno, A.M. Shrinkage, density, porosity and shape changes during dehydration of pumpkin (Cucurbita pepo L.) fruits. J. Food Eng. 2011, 103, 29-37. [CrossRef]

45. Alam, M.S.; Amarjit, S.; Sawhney, B.K. Response surface optimization of osmotic dehydration process for aonla slices. J. Food Sci. Technol. 2010, 47, 47-54. [CrossRef]

46. Grabowski, S.; Mujumdar, A.S.; Ramaswamy, H.S.; Strumillo, C. Osmo-convective drying of grapes. Dry. Technol. 1994, 12, 1211-1219. [CrossRef]

47. Mandala, I.G.; Anagnostaras, E.F.; Oikonomou, C.K. Influence of osmotic dehydration conditions on apple air-drying kinetics and their quality characteristics. J. Food Sci. 2005, 69, 307-316. [CrossRef]

48. Eren, I.; Kaymak-Ertekin, F. Optimization of osmotic dehydration of potato using response surface methodology. J. Food Eng. 2007, 79, 344-352. [CrossRef]

49. Giraldo, G.; Talens, P.; Fito, P.; Chiralt, A. Influence of sucrose solution concentration on kinetics and yield during osmotic dehydration of mango. J. Food Eng. 2003, 58, 33-43. [CrossRef]

50. Luchese, C.L.; Gurak, P.D.; Marczak, L.D.F. Osmotic dehydration of physalis (Physalis peruviana L.): Evaluation of water loss and sucrose incorporation and the quantification of carotenoids. LWT Food Sci. Technol. 2015, 63, 1128-1136. [CrossRef] 